\title{
Application of Historical Burn Analysis Method in Determining Agricultural Premium Based on Climate Index Using Black Scholes Method
}

\author{
Devi Ariyanti' ${ }^{1}$, Riaman ${ }^{2}$, Iin Irianingsih ${ }^{3}$ \\ 1,2,3Program Studi Matematika, Universitas Padjadjaran, Indonesia \\ 1deviariyanti5@gmail.com, 2riaman@unpad.ac.id, 3iin.irianingsih@gmail.com
}

\section{\begin{tabular}{l} 
\\
\hline Article History: \\
Received : 11-02-2020 \\
Revised : 27-03-2020 \\
Accepted : 28-03-2020 \\
Online : 02-04-2020
\end{tabular}}

Keyword:

Agricultural Insurance; Historical Burn

Analysis;

Black-Scholes;

Climate Index.

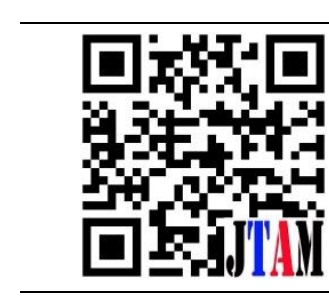

\section{ABSTRACT}

Farmers often suffer losses due to crop failure. The failure of the harvest is influenced by one of them is flooding, especially in Bandung which is quite frequent rain. Therefore one of the government's efforts to minimize losses from crop failures is the existence of an agricultural insurance program. The insurance system used is climate index insurance where the climate index is not plant insurance. This study aims to get a large premium to be paid by farmers using the Black-Scholes method. Meanwhile, to determine the climate index using the Historical Burn Analysis method. The results of this study are getting a variety of trigger values and exit values as well as the amount of premium that must be paid by farmers every planting season. Trigger values represent the minimum full payment limit. The exit value represents the maximum limit for no payment. The premium value obtained based on the selected trigger value also varies and is large enough so that it can be considered by farmers in choosing an agricultural insurance policy. Therefore, the method used must still be investigated to adjust to farmers, especially in Bandung.

\section{d.) 1 Crossref}

https://doi.org/10.31764/jtam.v4i1.1799

\section{(c) (1) (2)}

This is an open access article under the CC-BY-SA license

\section{A. INTRODUCTION}

Agriculture is one of the types of businesses that are more utilized by humans with a high enough consideration. Sources of risks and uncertainties that are external or which cannot be controlled by farmers generally come from the natural environment (Irawan, 2013), (Qosim, Dharmawan, \& Harini, 2018). In 2018, the agricultural sector accounts for 13,63 percent of national PDB. One type of agriculture that can be utilized by humans is food plants in the form of rice plants. Rice production in Indonesia averaged 57.428.884 tons annually. Rice farmers often experience losses due to crop failure. The harvest failure is influenced by several factors including the result of drought, flooding and plant pests (OPT) (Mutaqin, Kudus, \& Karyana, 2016). Therefore, to minimize losses due to crop failure, protection for farmers is needed. One of the government's efforts to protect farmers from loss is the holding of a Insurance Farmer Rice Program (AUTP). Currently, there have been many types of agricultural insurance developed based on the claims limit, such as insurance based on crop failure, yield, profit 
(revenue) and the latest is based on the climate index (weather index insurance) (Estiningtyas, 2015), (Kramer et al., 2016).

The main advantage of meteorological index based insurance compared to traditional insurance is that there is no need for damage assessment (Leblois \& Quirion, 2013). The use of climate indices in agricultural insurance is carried out because of the high correlation between climate events and crop losses (Wati, Estiningtyas, \& Fatkhuroyan, 2016). One way to calculate climate index insurance is to use the Historical Burn Analysis method (Taib \& Benth, 2012). In agricultural insurance there is also a premium that must be paid by farmers every harvest season. The premium calculation can be calculated based on the climate index using the Black-Scholes method.

Research on the climate index using the Historical Burn Analysis method has been carried out by Anggraeni et al (2018) who also used the Black-Scholes method to calculate the premium. The study took place in Bali's Jembrana Regency using data on average surface temperature and cocoa production. Sugiarto, Estiningtyas, \& Dewi (2017) conducted a Historical Burn Analysis method by taking a location in Pacitan Regency, East Java using data on rice dryness and pest attack data on rice plants, while analyzing its climate index using monthly moon rainfall data May to September. Widyawati, Satyahadewi, \& Sulistianingsih, (2013) conducted a study using the Black-Scholes model to determine the selling price of European type options, with the case study being the calculation of European type selling options on secondary closing price data from NOKIA corporations, Helmerich and Payne Inc., and SONY coorporation.

Therefore, based on previous research, we will discuss the calculation of agricultural insurance premiums based on climate indexes using the Historical Burn Analysis method to calculate the climate index and the Black-Scholes method to calculate the premiums. This study took place in Bandung Regency using daily rainfall data from October to April. Insurance that is covered is the price of coverage or initial capital of the farmer.

\section{B. METHODS}

\section{Object of Research}

The object of this research is climate index-based agricultural insurance premiums. The data used in this study are secondary data, namely daily rainfall data from 2014 to 2018 in Bandung Regency, which were obtained from the online data of the Meteorology, Climatology and Geophysics Agency (Badan Meteorologi, Klimatologi, 2019, dataonline.bmkg.go.id).

\section{Research Stages}

The stages carried out in this study are as follows:

a. Collecting daily rainfall data in Bandung Regency from 2014 to 2018 obtained from online data from the Meteorology, Climatology and Geophysics Agency.

b. Determine the climate index. The steps to determine the climate index using the Historical Burn Analysis method developed by IRI Columbia University (Sugiarto et al., 2017) are as follows:

1) Determination of window index

2) Calculating dasarian rainfall

3) Calculate the amount of "stamp"

4) Calculates the amount of rainfall that has been adjusted for each year

5) Compile rainfall data

6) Arrange exit and trigger values based on the selected reset period

c. Determine the amount of agricultural insurance premium in this study using the Black-Scholes method by taking into account the latest rainfall value, the trigger value of rainfall, variance or volatility, interest rates, time and value of coverage. 


\section{Black-Scholes Method}

Black \& Scholes, (1973) found an innovation to determine option prices. Some of the assumptions used are options that are used as a reference are European options that can only be used at maturity, the level of volatility of stock prices that are constant, shares used are not dividends, and there are no taxes and transaction costs in buying and selling options. Ross (2012) and Widyawati et al., (2013) wrote that the European type selling option prices determined by the Black-Scholes formula are as follows:

where

$$
P=K e^{-r T} N\left(-d_{2}\right)-S_{0} N\left(-d_{1}\right)
$$

$$
\begin{gathered}
d_{1}=\frac{\ln \left(\frac{S_{0}}{K}\right)+\left(r+\frac{\sigma_{T}{ }^{2}}{2}\right) T}{\sigma_{T} \sqrt{T}} \\
d_{2}=\frac{\ln \left(\frac{S_{0}}{K}\right)+\left(r-\frac{\sigma_{T}{ }^{2}}{2}\right) T}{\sigma_{T} \sqrt{T}}=d_{1}-\sigma_{T} \sqrt{T}
\end{gathered}
$$

With $P$ is option price, $S_{0}$ is initial stock price, $K$ is option strike price, $r$ is risk free interest rate, $\sigma_{T}$ is standard deviation of the stock price, $T$ is time until maturity, $N\left(-d_{1}\right)$ is cumulative density function of the normal distribution of $d_{1}, N\left(-d_{2}\right)$ is cumulative density function of the normal distribution of $d_{2}$. An explanation of the selling option price of equation (1) according to Dickson, Hardy, \& Waters, 2009) is generally written:

$$
P=e^{-r t} E\left(\operatorname{maks}\left(K-S_{T}, 0\right)\right)
$$

Option is a contract between the holder and writer (buyer) and seller (writer) in which the writer gives the right (not the obligation) to the holder to buy or sell the assets of the writer at a specified price (strike or exercise price) and at certain time in time (expiry date or maturity time) (Martin \& Ivanic, 2010), (Pramuditya, 2016). Selling options are contractual agreements that give the buyer the right to sell certain company shares in a certain amount from the seller of the option at a certain price and at a predetermined time (Gustyana \& Dewi, 2014). According to Black \& Scholes (1973) based on the stochastic process it is assumed that the stock price is distributed lognormal and the stock price follows the Brownian random geometric process. The stock price can be written as follows.

$$
S_{t}=S_{0} e^{\left(\mu-\frac{\sigma^{2}}{2}\right) T+{ }_{\sigma} W_{T}}
$$

Furthermore, the density function of equation (5) which is distributed lognormal can be written as follows

$$
g\left(S_{t}\right)= \begin{cases}\frac{1}{S_{t} \sigma \sqrt{2 \pi}} e^{-\frac{1}{2}\left(\frac{\ln S_{t}-\mu}{\sigma}\right)^{2}}, & S_{t}>0 \\ 0 & , S_{t} \leq 0\end{cases}
$$

where $\mu=\ln S_{0}+\left(r-\frac{\sigma^{2}}{2}\right) T$ and ${\sigma_{T}}^{2}=\sigma^{2} T$ (Mooy, Rusgiyono, \& Rahmawati, 2017). From equations (4) and (6) the selling options can be written.

$$
P=e^{-r T} \int_{K}^{\infty}\left(K-S_{t}\right) g\left(S_{t}\right) d S_{t}=e^{-r T}\left[K \int_{K}^{\infty} g\left(S_{t}\right) d S_{t}-\int_{K}^{\infty} S_{t} g\left(S_{t}\right) d S_{t}\right]
$$

From equation (7) it can be assumed to be:

$$
P=e^{-r T}\left[C_{1}-C_{2}\right]
$$


Furthermore, from equation (8) a solution is sought for the first integral example $C_{1}$ of equation (7)

$$
C_{1}=K \int_{K}^{\infty} g\left(S_{t}\right) d S_{t}
$$

In equation (9) the density function used is equation (6)

$$
C_{1}=K \int_{K}^{\infty} \frac{1}{S_{t} \sigma \sqrt{2 \pi}} e^{-\frac{1}{2}\left(\frac{\ln S_{t}-\mu}{\sigma}\right)^{2}} d S_{t}
$$

Equation (10) is changed in the form of a standard normal distribution with the example $z=\frac{\ln S_{t}-\mu}{\sigma_{T}}$, obtained $S_{t}=e^{\sigma z+\mu}$ and $d S_{t}=\sigma e^{\sigma z+\mu} d z$ so

$$
C_{1}=K \int_{K}^{\infty} \frac{1}{e^{\sigma z+\mu} \sigma \sqrt{2 \pi}} e^{-\frac{1}{2}(z)^{2}} \sigma e^{\sigma z+\mu} d z
$$

From equation (11) the integral limit is changed from $\mathrm{K}$ to $\frac{\ln K-\mu}{\sigma_{T}}$, because $\mu=\ln S_{0}+$ $\left(r-\frac{\sigma^{2}}{2}\right) T$ and $\sigma_{T}^{2}=\sigma^{2} T$ so

$$
C_{1}=K \frac{\int_{\ln K-\left(\ln S_{0}+\left(r-\frac{\sigma^{2}}{2}\right) T\right)}^{\infty}}{\sigma \sqrt{T}} \frac{1}{\sqrt{2 \pi}} e^{-\frac{1}{2}(z)^{2}} d z
$$

Because of the nature of the symmetrical normal distribution graph, equation (12) can be changed to

$$
C_{1}=K \int_{-\infty}^{\left(\frac{-\ln K+\ln S_{0}+\left(r-\frac{\sigma^{2}}{2}\right) T}{\sigma \sqrt{T}}\right)} \frac{1}{\sqrt{2 \pi}} e^{-\frac{1}{2}(z)^{2}} d z
$$

in general, equation (13) states the boundaries of the area covered by the normal curve at the limit of $-\infty$ to $\frac{-\ln K+\ln S_{0}+\left(r-\frac{\sigma^{2}}{2}\right) T}{\sigma \sqrt{T}}$ so that based on a normal distribution table it can be written as follows

$$
C_{1}=K \quad N\left(\frac{\ln \left(\frac{S_{0}}{K}\right)+\left(r-\frac{\sigma^{2}}{2}\right) T}{\sigma \sqrt{T}}\right)
$$

Then from equation (8) we also calculate the solution for the second integral, $C_{2}$ from equation (7)

$$
C_{2}=\int_{K}^{\infty} S_{t} g\left(S_{t}\right) d S_{t}
$$

In equation (15) the density function used is equation (6)

$$
C_{2}=\int_{K}^{\infty} S_{t} \frac{1}{S_{t} \sigma \sqrt{2 \pi}} e^{-\frac{1}{2}\left(\frac{\ln S_{t}-\mu}{\sigma}\right)^{2}} d S_{t}
$$

In equation (16), let's say $a=\ln S_{t}$, we get $e^{a}=e^{\ln S_{t}}$ and $d S_{t}=e^{a} d a$ so that

$$
C_{2}=\int_{K}^{\infty} \frac{1}{\sigma \sqrt{2 \pi}} e^{-\frac{1}{2}\left(\frac{a-\mu}{\sigma}\right)^{2}} e^{a} d a
$$


From equation (17) described as follows

$$
\begin{gathered}
C_{2}=\int_{K}^{\infty} \frac{1}{\sigma \sqrt{2 \pi}} e^{-\frac{a^{2}}{2 \sigma^{2}}+\frac{a \mu}{\sigma^{2}}-\frac{\mu^{2}}{2 \sigma^{2}}+a} d a \\
C_{2}=\int_{K}^{\infty} \frac{1}{\sigma \sqrt{2 \pi}} e^{-\frac{a^{2}}{2 \sigma^{2}}+\frac{a \mu}{\sigma^{2}}-\frac{\mu^{2}}{2 \sigma^{2}}+a+\frac{\sigma^{2}}{2}-\frac{\sigma^{2}}{2}+\mu-\mu} d a
\end{gathered}
$$

Then equation (18) is simplified and the integral limit is changed from $\mathrm{K}$ to $\ln K$ such that

$$
C_{2}=e^{\mu+\frac{1}{2} \sigma^{2}} \int_{\ln K}^{\infty} \frac{1}{\sigma \sqrt{2 \pi}} e^{-\frac{1}{2}\left(\frac{a-\left(\mu+\sigma^{2}\right)}{\sigma}\right)^{2}} d a
$$

Equation (19) is changed in the form of a standard normal distribution with the example $y=\frac{a-\left(\mu+\sigma^{2}\right)}{\sigma_{T}}$, so we get $d a=\sigma d y$. The limit for $\mathrm{K}$ is changed to $\frac{\ln K-\left(\mu+\sigma^{2}\right)}{\sigma_{T}}$, because it is known that $\mu=\ln S_{0}+\left(r-\frac{\sigma^{2}}{2}\right) T$ and $\sigma_{T}^{2}=\sigma^{2} T$ so that

$$
C_{2}=e^{\mu+\frac{1}{2} \sigma^{2}} \frac{\int_{\ln K-\left(\ln S_{0}+\left(r-\frac{\sigma^{2}}{2}\right) T+\sigma^{2} T\right)}^{\infty}}{\sigma \sqrt{T}} \frac{1}{\sqrt{2 \pi}} e^{-\frac{1}{2}(y)^{2}} d y
$$

From equation (20) the integral limit $\mathrm{K}$ is broken down into

$$
C_{2}=e^{\mu+\frac{1}{2} \sigma^{2}} \frac{\int_{\ln K-\left(\ln S_{0}+r T-\frac{\sigma^{2}}{2} T+\sigma^{2} T\right)}^{\infty \sqrt{T}}}{\sigma} \frac{1}{\sqrt{2 \pi}} e^{-\frac{1}{2}(y)^{2}} d y
$$

From equation (21) the integral limit $\mathrm{K}$ is summed to

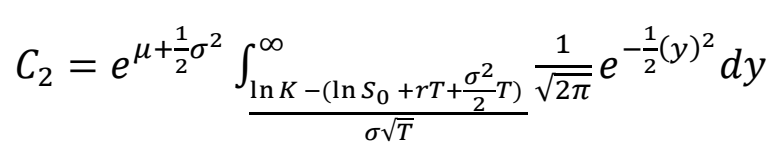

From equation (22) the integral limit $\mathrm{K}$ is simplified to

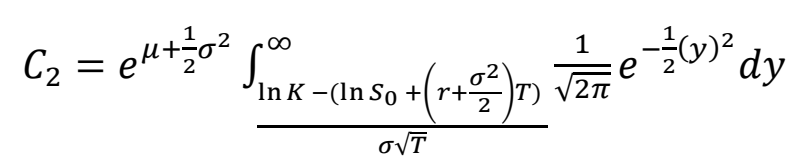

Due to the nature of the symmetrical normal distribution graph, so from equation (23) it can be changed to

$$
C_{2}=e^{\mu+\frac{1}{2} \sigma^{2}} \int_{-\infty}^{\left(\frac{-\ln K+\ln S_{0}+\left(r+\frac{\sigma^{2}}{2}\right) T}{\sigma \sqrt{T}}\right)} \frac{1}{\sigma \sqrt{2 \pi}} e^{-\frac{1}{2}(y)^{2}} \sigma d y
$$

in general, equation (24) states the boundaries of the area covered by the normal curve at the limit of $-\infty$ to $\frac{-\ln K+\ln S_{0}+\left(r+\frac{\sigma^{2}}{2}\right) T}{\sigma \sqrt{T}}$ so that based on a normal distribution table it can be written as follows

$$
C_{2}=e^{\mu+\frac{1}{2} \sigma^{2}} N\left(\frac{\ln \left(\frac{S_{0}}{K}\right)+\left(r+\frac{\sigma^{2}}{2}\right) T}{\sigma \sqrt{T}}\right)
$$


Because $\mu=\ln S_{0}+\left(r-\frac{\sigma^{2}}{2}\right) T$ and ${\sigma_{T}}^{2}=\sigma^{2} T$, so it can be substituted into

$$
C_{2}=e^{\ln S_{0}+\left(r-\frac{\sigma^{2}}{2}\right) T+\frac{1}{2} \sigma^{2} T} N\left(\frac{\ln \left(\frac{S_{0}}{K}\right)+\left(r+\frac{\sigma^{2}}{2}\right) T}{\sigma \sqrt{T}}\right)
$$

From equation (26) it can be decomposed into

$$
C_{2}=e^{\ln S_{0}+r T-\frac{\sigma^{2}}{2} T+\frac{1}{2} \sigma^{2} T} N\left(\frac{\ln \left(\frac{S_{0}}{K}\right)+\left(r+\frac{\sigma^{2}}{2}\right) T}{\sigma \sqrt{T}}\right)
$$

From equation (27) it can be simplified into

$$
C_{2}=S_{0} e^{r T} N\left(\frac{\ln \left(\frac{S_{0}}{K}\right)+\left(r+\frac{\sigma^{2}}{2}\right) T}{\sigma \sqrt{T}}\right)
$$

By substituting Equations (14) and (28) into Equation (8) is obtained

$$
P=e^{-r T}\left[K N\left(\frac{\ln \left(\frac{S_{0}}{K}\right)+\left(r-\frac{\sigma^{2}}{2}\right) T}{\sigma \sqrt{T}}\right)-e^{r t} N\left(\frac{\ln \left(\frac{S_{0}}{K}\right)+\left(r+\frac{\sigma^{2}}{2}\right) T}{\sigma \sqrt{T}}\right)\right]
$$

From equation (29) it can be simplified into

$$
P=K e^{-r T} N\left(d_{2}\right)-S_{0} N\left(d_{1}\right)
$$

where $d_{2}$ and $d_{1}$ re Equations (2) and (3). Based on the nature of the cumulative function a standard normal distribution is obtained

$$
P=K e^{-r T} N\left(-d_{2}\right)-S_{0} N\left(-d_{1}\right)
$$

Thus, equation (31) is known as the Black-Scholes model for the calculation of European type selling options.

In determining the price of insurance index using the Black-Scholes method can consider the following:

1. The benchmark value on index insurance is $\mathrm{H}$

2. Payment structure on index insurance is all at once

3. The index follows the Lognormal distribution

Logging in equation (3), the value of index-based agricultural insurance premiums can be calculated by finding the cumulative distribution value $d_{2}$ first with the following equation:

$$
d_{2}=\frac{\ln \left(\frac{R_{0}}{H}\right)+\left(r-\frac{\sigma^{2}}{2}\right) T}{\sigma \sqrt{T}}
$$

Where $R_{0}$ is the latest rainfall values, $H$ is trigger value (rainfall selected as index), $r$ is risk free interest rate, $\sigma$ standard deviation of the climate index, and $T$ is time. Thus, the value of agricultural insurance premiums based on rainfall index can be calculated by the equation:

$$
\text { Premi }=P e^{-r T} N\left(-d_{2}\right)
$$

Where $N\left(-d_{2}\right)$ is the probability of rainfall is less than the trigger value of rainfall, $r$ is risk free interest rate, $T$ is time. 


\section{RESULT AND DISCUSSION}

\section{Data}

The data used in this study are secondary data, namely daily rainfall data from 2014 to 2018 in Bandung Regency, which were obtained from the online data of the Meteorology, Climatology and Geophysics Agency (Badan Meteorologi, Klimatologi, 2019, dataonline.bmkg.go.id). Data is presented in graphical form and descriptive statistics using the help of Microsoft Excel 2010 software which aims to provide an overview of the data. The results of the data graph and descriptive statistical data can be seen as follows.

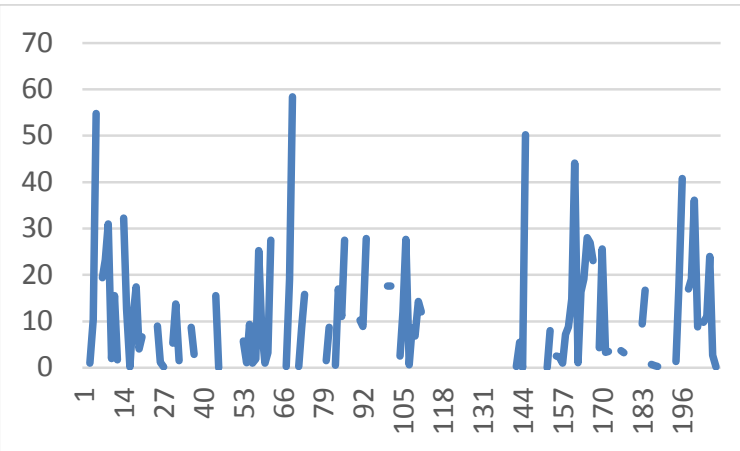

Figure 1. Daily Rainfall Data Graph 2014

Table 1. Statistics of Rainfall Data 2014

\begin{tabular}{lc}
\hline \multicolumn{1}{c}{ Parameters } & Value \\
\hline Mean & 11.094 \\
\hline Median & 8.600 \\
\hline Mode & 0.000 \\
\hline Standard Deviation & 12.259 \\
\hline Minimum & 0.000 \\
\hline Maximum & 58.40 \\
\hline
\end{tabular}

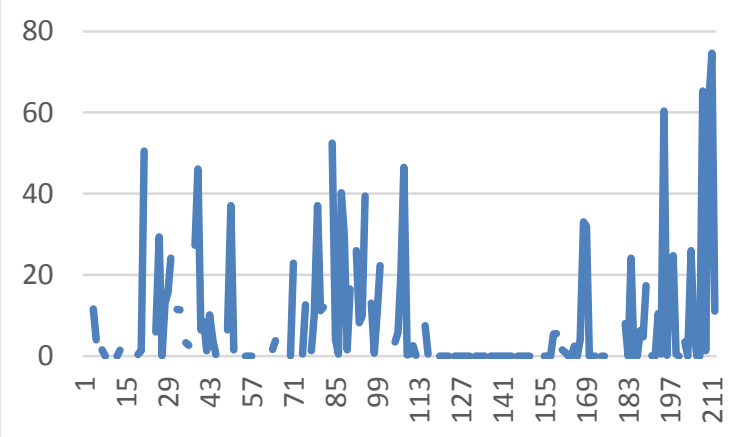

Figure 2. Daily Rainfall Data Graph 2015

Table 2. Statistics of Rainfall Data 2015

\begin{tabular}{lc}
\hline \multicolumn{1}{c}{ Parameters } & Value \\
\hline Mean & 8.845 \\
\hline Median & 1.500 \\
\hline Mode & 0.000 \\
\hline Standard Deviation & 14.918 \\
\hline Minimum & 0.000 \\
\hline Maximum & 74.60 \\
\hline
\end{tabular}

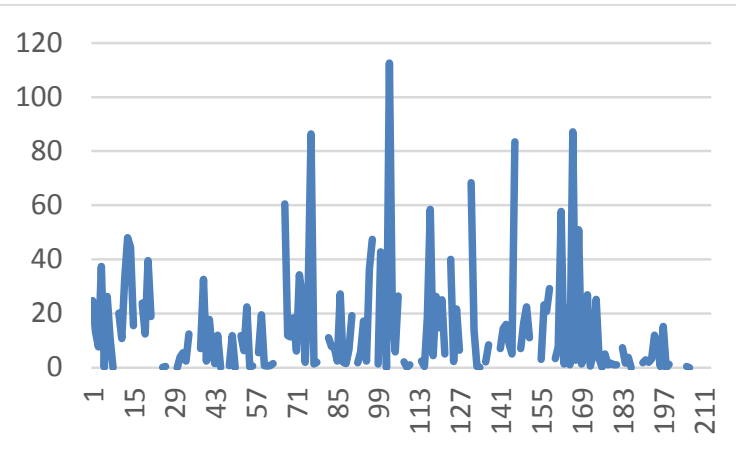

Figure 3. Daily Rainfall Data Graph 2016

Table 3. Statistics of Rainfall Data 2016

\begin{tabular}{lc}
\hline \multicolumn{1}{c}{ Parameters } & Value \\
\hline Mean & 14.340 \\
\hline Median & 6.900 \\
\hline Mode & 0.000 \\
\hline Standard Deviation & 19.229 \\
\hline Minimum & 0.000 \\
\hline Maximum & 112.6 \\
\hline
\end{tabular}

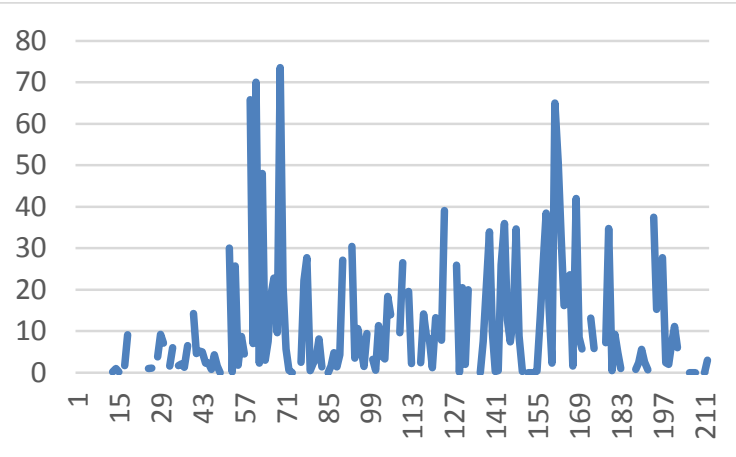

Figure 4. Daily Rainfall Data Graph 2017

Table 4. Statistics of Rainfall Data 2017

\begin{tabular}{lc}
\hline \multicolumn{1}{c}{ Parameters } & Value \\
\hline Mean & 10.933 \\
\hline Median & 5.600 \\
\hline Mode & 0.000 \\
\hline Standard Deviation & 14.478 \\
\hline Minimum & 0.000 \\
\hline Maximum & 73.50 \\
\hline
\end{tabular}




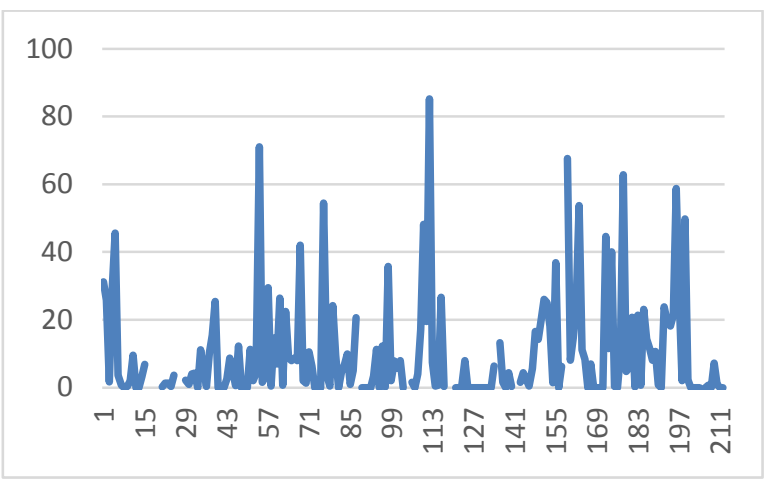

Table 5. Descriptive Statistics of Rainfall Data Year 2018

\begin{tabular}{lc}
\hline \multicolumn{1}{c}{ Parameters } & Value \\
\hline Mean & 9.951 \\
\hline Median & 3.650 \\
\hline Mode & 0.000 \\
\hline Standard Deviation & 15.168 \\
\hline Minimum & 0.000 \\
\hline Maximum & 85.200 \\
\hline
\end{tabular}

Figure 5. Daily Rainfall Data Graph 2018

\section{Determination of The Climate Index}

Determination of the climate index with rainfall as its climate type uses the Historical Burn Analysis method with the following steps

a. In this study, the window index was chosen based on the rainy season, which is from October to April from 2014 to 2018.

b. The dasarian rainfall calculated is the amount of 10 days of rainfall in the period to be insured (index window).

c. The stamp represents the maximum amount of rainfall calculated for each ten-day period (Masmoudi-Charfi \& Habaieb, 2014), (International Research Institute, 2010). The determination of the "cap" value is related to the daily potential evapotranspiration value (ETp) which can be seen in Table 6 below.

Table 6. Average ETp Value (mm/day)

(Allen, Pereira, Raes, \& Smith, 1998)

\begin{tabular}{|c|c|c|c|}
\hline \multirow[b]{2}{*}{ Region } & \multicolumn{3}{|c|}{ Average Daily Temperature $\left({ }^{\circ} \mathrm{C}\right)$} \\
\hline & $\begin{array}{c}\text { Cold } \\
\left(\sim 10^{\circ} \mathrm{C}\right)\end{array}$ & $\begin{array}{l}\text { Medium } \\
\left(\sim 20^{\circ} \mathrm{C}\right)\end{array}$ & $\begin{array}{c}\text { Warm } \\
\left(>30^{\circ} \mathrm{C}\right)\end{array}$ \\
\hline \multicolumn{4}{|c|}{ Tropical and subtropical } \\
\hline Moist and sub moist & $2-3$ & $3-5$ & $5-7$ \\
\hline Dry and semi-dry & $2-4$ & $4-6$ & $6-8$ \\
\hline
\end{tabular}

Potential evapotranspiration value (ETp) is a value that describes the energy needs obtained from the sun for the environment or agricultural areas. Factors that influence it include air temperature and air pressure.

The Bandung area has an average temperature of $23.5^{\circ} \mathrm{C}$ with a humidity level of $83 \%$ per day (Herianto; Hidayati, Asep Kurnia, Romdani, 2016). Therefore based on Table 6 the average value of the chosen ETp is $5 \mathrm{~mm}$ /day so that the value of "stamp" used per 10 days is $50 \mathrm{~mm}$. So the ETp value used in this study is $5 \mathrm{~mm} /$ day. Then the stamp value for 10 daily is $50 \mathrm{~mm}$.

d. Adjusted total rainfall or adjusted total rainfall is if the amount of rainfall for a ten-day period is less than the "cap", then the total rainfall used for that period. However, if in ten days the total rainfall is more than the "stamp", then the "stamp" is used. The stamp represents the maximum amount of rainfall calculated for each ten-day period.

e. The adjusted rainfall value (adjusted rainfall total) in each period insured is calculated by averaging for each period of ten days per year.

f. Preparation of rainfall data that has been adjusted (annually) from top to bottom starting from the highest rainfall to the lowest (giving rank). The results of determining the climate index can be seen in Table 7 below. 
Table 7. Rainfall Climate Index Every Year

\begin{tabular}{cc}
\hline Year & $\begin{array}{c}\text { The average rainfall is arranged } \\
(\mathbf{m m})\end{array}$ \\
\hline 2015 & 29.95 \\
\hline 2014 & 40.30 \\
\hline 2017 & 40.60 \\
\hline 2018 & 41.24 \\
\hline 2016 & 44.41 \\
\hline
\end{tabular}

g. The exit value is the lowest point where no payment is made. Exit is the lowest amount of rainfall in a year and is rounded up to the nearest integer. A trigger or trigger is a percentile of the amount of rainfall that has been adjusted. The results of determining the exit and trigger values can be seen in Table 8 below.

Table 8. Trigger and Exit Value from Climate Index Calculation Results

\begin{tabular}{ccc}
\hline Percentile & $\begin{array}{c}\text { Trigger } \\
\text { (mm) }\end{array}$ & $\begin{array}{c}\text { Exit } \\
\text { (mm) }\end{array}$ \\
\hline 20 & 32.02 & \\
\hline 30 & 38.23 & \\
\hline 40 & 40.42 & \\
\hline 50 & 40.60 & \multirow{2}{*}{29,95} \\
\hline 60 & 40.98 & \\
\hline 70 & 41.87 & \\
\hline 80 & 43.78 & \\
\hline
\end{tabular}

\section{Determination of The Sum Insured}

Determining the amount of agricultural insurance coverage in this study is based on the cost of rice production which includes capital and operational costs such as the cost of rice seeds, fertilizer, labor costs, and others. Based on the capital and operational costs, the coverage is IDR 6,430,000.00 / Ha.

\section{Determination of The Amount of Premium}

Determine the amount of agricultural insurance premiums in this using the Black-Scholes method using the equation (32) with the most recent rainfall $\left(R_{0}\right)$ being $878.4 \mathrm{~mm}$. $\mathrm{H}$ is the trigger value used for each percentile. $T$ is the selected time period that is $t=0.25 . r$ is the risk free interest rate $r=0.06$. The standard deviation or standard deviation $(\sigma)$ of the climate index is 4.90. After obtaining the cumulative distribution value of $d_{2}$ to calculate the amount of the agricultural insurance premium, using the equation (33).

In addition, descriptive statistics from the climate index can be seen in Table 9 as follows.

Table 9. Climate Index Descriptive Statistics

\begin{tabular}{lc}
\hline \multicolumn{1}{c}{ Parameters } & Value \\
\hline Mean & 39.30 \\
\hline Standard deviation & 4.90 \\
\hline Variance & 24.00 \\
\hline Maximum & 44.41 \\
\hline Minimum & 29.95 \\
\hline
\end{tabular}

The premium calculation for $H=32.02 \mathrm{~mm}$ is as follows 


$$
\begin{aligned}
& d_{2}=\frac{\ln \left(\frac{878,4}{32,02}\right)+\left(0,06-\frac{4,90^{2}}{2}\right) 0,25}{4,90 \sqrt{0,25}} \\
& d_{2}=0,133518601 \approx 0,13 \\
& N\left(-d_{2}\right)=N(-0,13)=0,4483
\end{aligned}
$$

Based on the results of the cumulative function calculation of $H=32.02 \mathrm{~mm}$ is 0.4483 , the calculation of the premium to be paid is.

$$
\begin{aligned}
& \text { Premium }=(\operatorname{IDR} 6.430 .000,00)\left(e^{-(0,06)(0,25)}\right)(0,4483) \\
& \text { Premium }=\operatorname{IDR} 2.839 .653,139
\end{aligned}
$$

So the amount of premium to be paid when choosing $\mathrm{H}=32.02 \mathrm{~mm}$ is IDR $2,839,653,139$. The amount of premium to be paid for other percentile values can be seen in Table 10 as follows

Table 10. Large Premiums to Be Paid

\begin{tabular}{cccc}
\hline Percentile & Rainfall $(\mathbf{m m})$ & Price Coverage (IDR) & Premium (IDR) \\
\hline 20 & 32.02 & $6,430,000,00$ & $2,839,653,13$ \\
30 & 38.23 & $6,430,000,00$ & $3,318,523,93$ \\
40 & 40.42 & $6,430,000,00$ & $3,268,483,20$ \\
50 & 40.60 & $6,430,000,00$ & $3,268,483,20$ \\
60 & 40.98 & $6,430,000,00$ & $3,243,146,12$ \\
70 & 41.87 & $6,430,000,00$ & $3,217,809,04$ \\
80 & 43.78 & $6,430,000,00$ & $3,192,471,96$ \\
\hline
\end{tabular}

Table 10 shows the agricultural insurance premiums that must be paid every planting season or three months per hectare. It can be seen that with varying rainfall values, premium payments vary. This can be used by farmers to consider purchasing policies based on the selected rainfall.

\section{CONCLUSION AND SUGGESTIONS}

From the climate index, various trigger values are obtained from the percentile of climate index per year. However, the exit value is the smallest value of the climate index per year. Trigger values represent the minimum limit for full payment. While the exit value represents the maximum limit of no payment. If rainfall occurs between the exit and trigger values, then a partial payment.

Calculation of premiums using the Black-Scholes method is based on a variety of trigger values using the cumulative nature of the standard normal distribution function approach which then produces a large premium that also varies. This large premium value can occur because of the relatively short duration of time only per park period or once every three months for payment. This can be a consideration for farmers, especially in Bandung regency in choosing agricultural insurance policies.

The advice that can be submitted by the author is that the premiums that are obtained are considered to be of considerable value if paid to a farmer. Therefore the farmer group is very important and can be used to purchase this climate index-based agricultural insurance policy. In addition, the method used is a simple method so that for future research another method can be used that can get a premium value that can be adapted to the farmers.

\section{REFERENCES}

Allen, R. G., Pereira, L., Raes, D., \& Smith, M. (1998). FAO Irrigation and Drainage ${ }^{\circ} 56$ : Guidelines for Computing Crop Water Requirements. Irrigation and Drainage, 300(56), 326. https://doi.org/10.1016/j.eja.2010.12.001

Anggraeni, A. M., Dharmawan, K., \& Nilakusmawati, D. P. . (2018). Penentuan Nilai Premi Asuransi 
Pertanian Berbasis Indeks Suhu Permukaan Menggunakan Metode Burn Analysis. E-Jurnal Matematika, 7(4), 322-329.

Badan Meteorologi, Klimatologi, dan G. (2019). Data Online Pusat Database.

Black, F., \& Scholes, M. (1973). The pricing of options and corporate liabilities. Journal of Political Economy, 81, 637-654.

Dickson, D. C., Hardy, M. R., \& Waters, H. R. (2009). Actuarial Mathematics for Life Contingent Risks. Cambridge University Press.

Estiningtyas, W. (2015). Asuransi Pertanian Berbasis Indeks Iklim: Opsi Pemberdayaan dan Perlindungan Petani Terhadap Risiko Iklim. Jurnal Sumberdaya Lahan, 9, 51-64.

Gustyana, T. T., \& Dewi, A. S. (2014). Analisis Perbandingan Keakuratan Harga Call Option Dengan Menggunakan Metode Monte Carlo Simulation dan Metode Black Scholes Pada Indeks Harga Saham Gabungan (IHSG). Jurnal Manajemen Indonesia, 14.

Herianto; Hidayati, Asep Kurnia, Romdani, A. (2016). Evapotranspirasi referensi dua daerah di jawa barat untuk analisis perencanaan kebutuhan air irigasi. Siliwangi Seri Sains Dan Teknologi, 2(2), 138-142.

Irawan, M. I., Syaharuddin, Utomo, D. B., \& Rukmi, A. M. (2013). Intelligent irrigation water requirement system based on artificial neural networks and profit optimization for planting time decision making of crops in Lombok Island. Journal of Theoretical and Applied Information Technology, 58(3), 657-671.

Kramer, R. M., Bank, E., Cds, T. S., Cds, S. S. S. S. S., Cds, C., According, H., ... Bystrom, H. (2016). Linkages Between Stock Market and Sovereign Credit Default Swaps Market. Journal of Banking and Finance. https://doi.org/10.1016/j.qref.2005.11.007

Leblois, A., \& Quirion, P. (2013). Agricultural insurance based on meteorological indices: realizations, methods and research challenges. Meteorological Applications, 20, 1-9.

Martin, W., \& Ivanic, M. (2010). The food price crisis, poverty and agricultural trade policy. In Food Crises and the WTO: World Trade Forum (pp. 25-48). https://doi.org/10.1017/CB09780511712005.003

Masmoudi-Charfi, C., \& Habaieb, H. (2014). Rainfall Distribution Functions for Irrigation Scheduling: Calculation Procedures Following Site of Olive (\&lt;i\&gt;Olea europaea\&lt;/i\&gt; L.) Cultivation and Growing Periods. American Journal of Plant Sciences, 05(13), 2094-2133. https://doi.org/10.4236/ajps.2014.513224

Mooy, M. N., Rusgiyono, A., \& Rahmawati, R. (2017). Penentuan Harga Opsi Put dan Call Tipe Eropa Terhadap Saham Menggunakan Model Black-Scholes. JURNAL GAUSSIAN, 6, 407-417.

Mutaqin, A. K., Kudus, A., \& Karyana, Y. (2016). Metode Parametrik Untuk Menghitung Premi Program Asuransi Usaha Tani Padi Di Indonesia. Ethos (Jurnal Penelitian Dan Pengabdian Masyarakat), 4, 318-326.

Pramuditya, S. A. (2016). Perbandingan Metode Binomial dan Metode Black-Scholes Dalam Penentuan Harga Opsi. Jurnal Sainsmat, $V, 1-6$.

Qosim, S., Dharmawan, K., \& Harini, L. P. I. (2018). Penentuan Harga Premi Asuransi Pertanian Berbasis Indeks Curah Hujan Dengan Menggunakan Metode Pembangkit Distribusi Eksponensial Campuran. E-Jurnal Matematika, 7(2), 141-147.

Ross, S. M. (2012). The Black-Scholes Formula. In An Elementary Introduction to Mathematical Finance (pp. 95-117). https://doi.org/10.1017/cbo9780511800634.008

Sugiarto, Y., Estiningtyas, W., \& Dewi, W. S. (2017). Analisis Indeks Iklim dengan Metode Historical Burn Analysis untuk Adaptasi Perubahan Iklim (Studi Kasus di Kabupaten Pacitan, Jawa Timur). Argomet, 1-10.

Taib, C. M., \& Benth, F. E. (2012). Pricing of Temperature Index Insurance. ScienceDirect, 22-31.

Wati, T., Estiningtyas, W., \& Fatkhuroyan. (2016). Analisis Indeks Iklim Untuk Asuransi Pertanian Tamanam Padi Di Kabupaten Cirebon Dalam Rangka Adaptasi Perubahan Iklim. Jurnal Meteorologi Dan Geofisika, 17, 129-137.

Widyawati, Satyahadewi, N., \& Sulistianingsih, E. (2013). Penggunaan Model Black Scholes Untuk Penentuan Harga Opsi Jual Tipe Eropa. Buletin Ilmiah Math. Stat. Dan Terapannya (Bimaster), 02, 13-20. 